\title{
REVISTAMARACANAN
}

Dossiê

\section{Impressões da guerra: as relações de sucesso lisboetas e madrilenas sobre a Restauração Portuguesa (1640-1668)}

\author{
Impressions of the war: The Lisbon and Madrillenian "relações de sucesso" \\ concerning the Portuguese Restoration (1640-1668)
}

Recebido em: 30 abr. 2021.

Aprovado em: 5 ago. 2021

\section{Caroline Garcia Mendes*}

Universidade Estadual de Campinas

Campinas, São Pauo, Brasil

[Este artigo é desdobramento da tese de doutorado chamada Gazetas, Mercúrios e Relações de Sucesso: a produção e a circulação de notícias impressas na Península Ibérica na segunda metade do século XVII, publicada em livro no ano de 2021 com o título de Nos prelos da Restauração Portuguesa. "Dar ao mundo verdadeira notícia". Essa pesquisa foi financiada pela Fundação de Amparo à Pesquisa do Estado de São Paulo (FAPESP) - processo 2014/23614-7]

* Pesquisadora Colaboradora no IFCH/Unicamp. Doutora em História Social pela Universidade de São Paulo. Mestra em História pela Universidade Estadual de Campinas. Bacharel e Licenciada em História pela Universidade Federal de Viçosa. (carol.mendes@outlook.com)
(D) https://orcid.org/0000-0003-3293-6156
(9) http://lattes.cnpq.br/2177565007492203 


\title{
Resumo
}

Buscando contribuir com os recentes debates sobre o fenômeno das relações de sucesso no continente europeu, esse trabalho visa discutir a publicação desses impressos de notícias em Lisboa e Madrid durante o período da Restauração Portuguesa. A partir da seleção desses documentos, discorremos sobre os usos das relações de sucesso para informar sobre a guerra, enaltecer oficiais e grupos de soldados e atacar os inimigos através de relatos no intuito de desmoralizá-los. Além disso, apontamos os principais recursos utilizados nos dois lados da fronteira para tratar do inimigo: se os castelhanos eram hereges e violentos nos impressos lisboetas, os papéis madrilenos publicavam que os portugueses estavam sendo enganados por um rebelde que precisava ser derrotado. A quantidade de impressos produzidos em Lisboa foi bastante superior ao que foi publicado em Madrid, e neles podemos encontrar ainda a participação de mulheres no conflito e menções a Bandarra e suas profecias.

Palavras-chave: Relações de sucesso. Guerra da Restauração. Cultura escrita.

\begin{abstract}
Seeking to contribute to the recent debates concerning the phenomenon of the "relações de sucessos" in the European continent, this study aims at discussing the publication of these printed news in Lisbon and Madrid during the period of the Portuguese Restoration. Considering a selection of these documents, it is analyzed the uses of the "relações de sucesso" to inform about the war, to praise officers and groups of soldiers as well as to attack the enemies through these reports with a view to demoralize them. Furthermore, the main rhetoric resources employed by both sides of the conflict to characterize the enemy are discussed: if the Castilians were heretics and violent in the Lisbon printed news, the Madrilenian papers informed that the Portuguese were being deceived by a rebel that needed to be defeated. The amount of printed news produced in Lisbon was significantly higher than the one published in Madrid, and in them, it is also possible to read about the participation of women in the conflict and mentions to Bandarra and his prophecies.
\end{abstract}

Keywords: "Relações de sucesso". War Restoration. Written Culture. 
Os estudos sobre relações de sucesso vem recebendo grande atenção nas últimas décadas, sobretudo com a percepção de que esse material está presente em todo o continente europeu, ainda que durante muito tempo tenha sido estudado apenas a partir de histórias regionais. A História da Sociedad Internacional para el Estudio de las Relaciones de Sucesos é um exemplo de como esse tema foi se construindo ao longo dos anos e unindo pesquisadores de diferentes partes do mundo na busca por compreender uma documentação específica da Época Moderna. Na apresentação da primeira ata publicada, seus editores explicam que, após o III Congreso de la Asociación Internacional Siglo de Oro no ano de 1993, foi percebido um interesse comum de vários pesquisadores sobre o estudo das relações de sucesso e um "vacío crítico que estos textos tenían en el panorama general de los estúdios áureos, centrados tan sólo ocasionalmente en algunas de las 'relaciones' em prosa y habitualmente desde una perspectiva meramente enunciativa de su condición bibliográfica". ${ }^{1}$ A "reunião monográfica" que se seguiu dessa percepção no ano de 1995 na Universidade de Alcalá de Henares contou com a participação de cerca de trinta pesquisadores e deu origem à primeira publicação do grupo no ano seguinte. Apenas no ano de 1998 a sociedade foi de fato criada, e a cada três anos seus membros continuam organizando encontros em diferentes universidades europeias com a proposta de ampliar a discussão sobre as relações de sucessos, disponibilizando as publicações em seu site para a divulgação das pesquisas sobre este tema. ${ }^{2}$

A organização desses e de outros encontros certamente contribuiu para a concepção continental do fenômeno das relações de sucesso. O historiador Henry Ettinghausen argumenta que títulos como "relaciones de sucesos, avvisi a stampa, occasionnels, canards, newsletters, Flugschriften, Flugblätter ou Neue Zeitungen" fizeram com que estes documentos fosse estudados de maneira regional ainda que fossem um fenômeno pan-europeu. ${ }^{3}$ Dessa forma, é crescente nos últimos anos a busca por uma análise comparada que consiga compreender melhor a dinâmica das relações de sucesso em diferentes partes do continente. Carmen Espejo

\footnotetext{
${ }^{1}$ GARCÍA DE ENTERRÍA, María Cruz. et al. Presentación. In. Las relaciones de sucesos en España (15001750). Actas del primer Coloquio Internacional (Alcalá de Henares, 8, 9 y 10 de junio de 1995). Publications de la Sorbonne. Servicio de Publicaciones de la Universidad de Alcalá, 1996. p. 7.

2 Todas as atas da SIERS estão em: <https://siers.es/publicacion/acta/listar.htm> Acesso dia 28-abr2021.

3 ETTINGHAUSEN, Henry. Relaciones Internacionales: las relaciones de sucesos, un fenómeno paneuropeo. In: GARCÍA LÓPEZ, Jorge. BOADAS, Sònia (eds.) Las relaciones de sucesos en los cambios políticos y sociales de la Europa Moderna. Sociedad Internacional para el Estudios de las Relaciones de Sucesos. Universitat Autònoma de Barcelona; Servei de Publicacions: Bellaterra, 2015. p. 17.
} 
Cala e Francisco Baena Sánchez, por exemplo, propõem um vocabulário comum para tratar desses "impressos noticiosos", buscando a construção e ampliação de um banco de dados digital que abarque todos estes documentos. ${ }^{4}$ Além disso, várias obras que buscam tratar da difusão de notícias pensando diferentes regiões da Europa vem sendo publicadas, como o livro News Networks in the Early Modern Europe que, nos primeiros capítulos, discorre de maneira comparada sobre os impressos de notícias e as redes postais das principais cidades europeias, ressaltando que a história das notícias na Época Moderna foi marcada por "national narratives, narratives that risk ignoring or downplaying the extent to which news and its circulation were transnational phenomena". ${ }^{5}$

A proposta deste trabalho é bem mais modesta do que os exemplos acima, mas se inspira neles para pensar as relações de sucessos publicadas em Lisboa e Madrid durante a guerra da Restauração (1640-1668). É surpreendente perceber que, apesar da grande quantidade de material publicado em Portugal nesse período, muitas vezes esses impressos são deixados de lado nas propostas que pensam uma discussão continental. A Gazeta de Lisboa, de início do século XVIII, é o documento mais lembrado quando se trata de Portugal, o que se deve provavelmente ao trabalho pioneiro do historiador André Belo. ${ }^{6}$ As relações de sucesso espanholas, por outro lado, são discutidas em vasta produção historiográfica, ainda que os documentos que apresentaremos neste trabalho recebam menos atenção dos pesquisadores do que impressos que trazem notícias de festas, naufrágios, monstros e milagres - chamados por Henry Ettinghausen de prensa amarilla. ${ }^{7}$ Buscamos, assim, discorrer sobre essas relações pensando o contexto no qual estavam inseridas e abordando os principais assuntos que eram tratados nesses impressos, tendo em vista o intuito português de enaltecer a Coroa de Bragança e garantir sua separação da Monarquia Hispânica, além do propósito castelhano de demonstrar que Portugal continuaria sob seus domínios.

\section{A Restauração Portuguesa e a publicação de notícias}

O conflito entre Portugal e a Monarquia Hispânica começou após sessenta anos de anexação do reino português aos domínios filipinos. Se em 1580 a nobreza portuguesa se viu

\footnotetext{
${ }^{4}$ BAENA SÁNCHEZ, Francisco. ESPEJO CALA, Carmen. En busca de un vocabulario compartido para describir y representar el periodismo de la Edad Moderna. In: CIAPELLI, Giovanni. NIDER, Valentina (eds.) La invención de las noticias. Las relaciones de sucesos entre la literatura y la información (siglos XVI-XVIII). Trento: Università degli Studi di Trento. Departimento di Lettere e Filosofia, 2017. p. 107-130. O termo "impressos noticiosos" sugeridos pelos historiadores abarca não só as relações de sucesso, mas também os periódicos impressos de notícias, como as gazetas.

5 ABLASTER, Paul. et al. The lexicons of Early Modern News. In: RAYMOND, Joad. MOXHAM, Noah (ed.) News Networks in Early Modern Europe. Brill: Leiden; Boston, 2016. p. 64.

6 BELO, André. As Gazetas e os Livros. A Gazeta de Lisboa e a vulgarização do impresso (1715-1760). Lisboa: Instituto de Ciências Sociais, 2001.

7 ETTINGHAUSEN, Henry. Prensa amarilla y Barroco español. In: CHARTIER, Roger. ESPEJO Carmen (eds.) La aparición del periodismo en Europa. Comunicación y propaganda en el Barroco. Marcial Pons: Madrid, 2012. Ainda sobre o tema: ETTINGHAUSEN, Henry. Noticias del siglo XVII: Relaciones Españolas de sucesos naturales y sobrenaturales. Barcelona: Puvill Libros, 1995.
} 
contemplada nas ofertas de Felipe II - e o exército filipino às portas de Lisboa certamente contribuiu com isso -, em 1640 parte dessa mesma nobreza se organizou para colocar no trono a dinastia brigantina na figura de dom João, oitavo duque de Bragança. Em primeiro de dezembro de 1640, assim, o movimento foi colocado em prática, com o assassinato do secretário de Estado Miguel de Vasconcellos e a prisão de Margarida de Saboia, representantes do governo castelhano em Portugal. ${ }^{8}$ A partir desse momento, uma grande quantidade de impressos noticiosos começou a ser publicado, especialmente na cidade de Lisboa, discorrendo não só sobre a situação nas fronteiras, mas também acerca das embaixadas que começam a ser enviadas em nome da nova Coroa. Enquanto isso, a situação pela qual passava a Monarquia fez com que os impressos pouco discorressem sobre as questões portuguesas, especialmente porque se acreditava que em pouco tempo Portugal seria recuperado.

A produção de relações de sucesso sobre a guerra da Restauração em Portugal alcançou um número bastante superior do que o impresso em Castela. Escolhemos assim as cidades sedes destas Coroas para analisar o material impresso de notícias que foi publicado neste período, ainda que certamente não tenhamos lido tudo o que foi produzido nestas localidades. ${ }^{9}$ Nos quase trinta anos de duração da guerra, foram impressos centenas de papéis, sobretudo do lado português, argumentando sobre a validade do movimento de dezembro de 1640 e as razões que levaram à aclamação de dom João IV. Preocupados com outras frentes de batalha, pouco se imprimiu em Madrid sobre Portugal até o final da década de 50 do século XVII. A década de 40 do lado castelhano ficou marcada pelos manifestos contra os Braganças e a "traição" perpetrada pela maior casa portuguesa, que discorriam acerca do direito de Felipe II e também, portanto, de seu neto, ao poder sobre Portugal. Em um momento em que os vassalos dos dois lados buscavam reconhecimento através da menção de seus nomes nos papéis de notícia, numa "propaganda em escala menor" - e por outro lado eram ridicularizados proporcionalmente a sua função nas batalhas e títulos que carregavam -, Lisboa passou a produzir incessantemente desde janeiro de 1641 dezenas de relações de sucesso, e a partir de 1642 concomitante a elas sua Gazeta "da Restauração". A Monarquia Hispânica, por sua vez, e Madrid, no nosso estudo, somente na última década da guerra passou a publicar relações de sucesso - e também sua Gazeta - discorrendo sobre as batalhas contra Portugal.

A historiadora Ana Paula Torres Megiani explica que relações de sucesso são "textos ocasionais, sem periodicidade regular, nos quais são relatados acontecimentos com o objetivo

\footnotetext{
8 Há vasta bibliografia sobre o tema. Ver: CARDIM, Pedro. Portugal Unido y Separado. Felipe II, la unión de territorios y el debate sobre la condición política del Reino de Portugal. Valladolid: Cátedra Felipe II; Ediciones Universidad de Valladolid, 2014; COSTA, Fernando Dores. A Guerra da Restauração 1641-1668. Lisboa: Livros Horizonte, 2004; COSTA, Leonor Freire. CUNHA, Mafalda Soares da. D. João IV. Círculo de Leitores, Lisboa, 2008; FRANÇA, Eduardo d'Oliveira. Portugal na Época da Restauração. Hucitec: São Paulo, 1997; VALLADARES, Rafael. A independência de Portugal. Guerra e Restauração (1640-1680). Trad. de Pedro Cardim. A Esfera dos Livros: Lisboa, 2006; VALLADARES, Rafael. Portugal y la Monarquía Hispánica 1580-1668. Arco Libros: Madrid, 2000.

9 Outras cidades da atual Espanha eram famosos centros impressores já naquela época, como Sevilha e Barcelona. A escolha por Madrid se deu exclusivamente por ser a sede da coroa castelhana, assim como Lisboa era a capital portuguesa.
} 
de informar, entreter e comover o receptor sobre 'coisas que têm sucedido'. ${ }^{10}$ Em sua maioria apresentavam, assim, uma capa com o título, o nome da oficina impressora, a cidade e o ano de impressão. Algumas vezes continham xilogravuras que chamassem a atenção do público leitor, ainda que não as tenhamos encontrado com frequência, tendo em vista a rapidez com que tinham que circular e o preço baixo que possuíam. Eram papéis impressos na medida em que a oportunidade permitisse, marcados pela chegada de notícias às cidades em que as oficinas impressoras se localizavam.

As relações de sucesso podem ser divididas em dois grupos principais: voltadas para a divulgação de notícias fantásticas e excepcionais como naufrágios, milagres e aparições de monstros e um grupo que discorre sobre ações de governo, tanto do âmbito bélico como do diplomático, discorrendo sobre as frentes armadas, os encontros e movimentações dos exércitos e também sobre o envio de embaixadores e acordos firmados entre os reinos europeus. É esse segundo conjunto de documentos o tema deste trabalho: impressos de notícias que informam aos leitores sobre os acontecimentos envolvendo Castela e Portugal relacionados à guerra da Restauração. Reiteramos assim, que partimos de um levantamento realizado tanto na Biblioteca Nacional de Portugal como na Biblioteca Nacional da Espanha buscando identificar relações de sucesso produzidas nas duas cidades no período do conflito. Sabemos que dificilmente esgotamos essa documentação, tendo em vista sua quantidade e dispersão pelo continente. A análise proposta demonstra suas principais características e seu papel em um momento político importante para as duas Coroas.

\section{As relações lisboetas}

É bastante expressiva a quantidade de relações de sucesso impressas em Lisboa nos primeiros anos após a aclamação de dom João IV e convém para este trabalho discorrermos sobre os principais temas relacionados à guerra que foram abordados por estes papéis. Encontramos nas duas cidades relações que podemos definir como "seriadas", ou seja, que apresentavam uma sequência onde o leitor poderia acompanhar as batalhas. Aparentemente essas relações são publicadas com a oportunidade da notícia, mas não há a periodicidade encontrada em gazetas e mercúrios já que, no caso dos periódicos, os editores abastecem um título já existente com notícias que chegam através das redes de correspondência já consagradas no continente europeu. ${ }^{11}$ Carmen Espejo Cala e Francisco Baena Sanchez

\footnotetext{
10 MEGIANI, Ana Paula Torres. Contar coisas de todas as partes do mundo: as Relaciones de Sucesos e a circulação de notícias escritas no período filipino. In: ALMEIDA, Suely Creusa Cordeiro de. SILVA, Gian Carlo de Melo. RIBEIRO, Marília de Azambuja (orgs.) Cultura e sociabilidades no mundo atlântico. Recife: Ed. Universitária da UFPE, 2012. p. 473.

11 Sobre o tema, ver: SCHOBESBERGER, Nikolaus. et. al. European Postal Network. In: RAYMOND, Joad. MOXHAM, Noah (ed.) News Networks in Early Modern Europe. Brill: Leiden; Boston, 2016. p. 19-63.
} 
também definem esses impressos como relações seriadas, explicando que "no hay periodicidad reconocible, pero sí cierta continuidade". ${ }^{12}$

Encontramos impressas em Lisboa quatro relações de sucesso seriadas que possuíram dois impressores diferentes em sua produção. Pelas datas da taxação obrigatória (Anexo 1) podemos conferir a frequência com que os papéis que tratam das ações de Ruy Figueiredo foram impressos e perceber certo padrão de comportamento dos impressores das duas cidades ao publicarem relações de sucesso seriadas nos dois tempos distintos da guerra: para Portugal, no ano seguinte à aclamação e portanto momento fundamental de impressão de notícias; para Castela como veremos, na última década da guerra, quando Felipe IV e seu exército se voltou para o reino ocidental e necessitava demonstrar suas vitórias e sua força diante dos vassalos rebeldes e também do restante da Europa. ${ }^{13}$ Além disso, apenas pelos títulos das relações seriadas elencadas no Anexo 1 podemos perceber uma semelhança entre os impressos das duas cidades: a descrição dos feitos bélicos dos oficiais enviados também era uma constante.

A primeira relação é assinada pelo próprio Ruy Figueiredo, que descreve sua entrada na região da Galícia após receber uma carta de Sua Majestade mandando que "rompesse guerra com o inimigo". Após três entradas feitas de maneira simultânea, lemos que os moradores da região se entregavam com pouca resistência e "querião ser vassalos de el Rey de Portugal, \& mãdar suas fazendas, \& famílias pera este Reyno, \& por isso os fui deixando com o nome de vassallos obedientes, sem lhe fazer mais dano que o que receberão nas entradas." ${ }^{14}$ A relação se encerra concluindo que

Temos cá entendido com fundamentos muito certos, que os Gallegos estão com tam grande medo desta entrada, \& do que tem sabido das nossas armas, que se eu tiuer moniçoes bastantes para me poder deter em Galiza, farei por toda ella grande estrago. V. M. me faça mercê de o representar assi a sua Magestade, \& saber delle o que mais me manda que faça, porque o desejo que tenho de me empregar em seu serviço helhe muito prezente $(\ldots) .^{15}$

Os galegos, dessa forma, estariam com medo das entradas portuguesas e a vitória dependia do envio de mantimentos para a região, afirmando Ruy Figueiredo o gosto que tinha em obedecer às ordens de dom João IV. Além disso, da mesma maneira que as relações de sucesso madrilenas descrevem que os portugueses das fronteiras estariam passando para o lado deles, nos papéis lisboetas os galegos também estariam do lado português.

Como os títulos das demais relações apontam, elas teriam sido retiradas de cartas escritas por Ruy Figueiredo para o rei português, e eram escritas em primeira pessoa tratando

\footnotetext{
12 BAENA SÁNCHEZ, Francisco. ESPEJO CALA, Carmen. En busca de un vocabulario compartido para describir y representar el periodismo de la Edad Moderna... p. 117.

13 No ano de 1662 também encontramos em Lisboa uma indicação de relação seriada, mas no acervo da Biblioteca Nacional de Portugal há infelizmente apenas uma delas: Relaçam terceira e qvarta da victoria qve o Conde de Villa Flor Dom Sancho Manvel Gouernador das Armas da Prouincia da Beira alcançov das Armas Castelhanas a noue \& a dez de Agosto deste anno de 662. Impressor Domingos Carneiro.
}

${ }^{14}$ Relaçam do svcesso qve Ruy de Figveiredo fronteiro d'Arraya de tralos montes teue na entrada que fez no Reyno de Galiza. 1641. Impressor: Manoel da Silva. f.2.

15 Ibidem. f. 3v-4. 
do andamento dos encontros com os castelhanos na região da Galícia. Será uma constante nas relações descrever um momento particular do acontecimento com o intuito de passar a ideia de veracidade, por aparentar terem sido escritas diretamente do front. Em outra relação, por exemplo, o texto também em primeira pessoa afirma que escrevia por ser "historia conhecida o relato a V.M. como testemunha de vista, para que o comunique aos amigos." 16 Por fim, encontramos na quarta e última relação da série uma demonstração da devoção portuguesa: num momento da batalha em que castelhanos se escondem em uma Igreja e dali continuam proferindo ataques, a relação afirma que um dos oficiais sugere queimar o templo para desalojálos, ao que o outro oficial teria respondido que "mais queria que ficassem o dito Conde, \& Marques, que por em risco as cousas sagradas: porque assi lho ordenaua sua Magestade, cujo piadoso zelo \& Religião não queria ganhar monarquias com menor desacato do Diuino culto". ${ }^{17}$ A devoção portuguesa à religião católica, aliada à profanação perpetrada aos templos pelos castelhanos era também uma constante nos papéis de notícias portugueses. As relações impressas em Lisboa buscam enfatizar ainda a violência dos castelhanos e seu costume de fugir do campo de batalhas, exaltando sua covardia e inabilidade para a guerra. ${ }^{18}$

No intuito de realçar ainda mais o brio do povo português, essas relações traziam algumas vezes a participação de mulheres no enfrentamento do exército inimigo, demonstrando assim que mesmo uma mulher era capaz de derrotar os castelhanos. É o que inferimos ao lermos que dentre os duzentos inimigos mortos, nove foram mortos por "hua moça donzela, \& nobre, em defenção de sua casa, \& honra, cuja valerosa acção merece ficar eternizada para sempre."19 A ação da moça ao matar nove castelhanos deveria, assim, ser eternizada através da publicação na relação de sucesso. Outras mulheres aparecem ainda nos papéis de notícias impressos em Lisboa, descrevendo com mais detalhes suas ações dentro da batalha:

Aqui vimos renouadas as façanhas nam só dos homes, mas ainda das mulheres Portuguezas, de que fazem mençam as Chronicas Romanas, \& as nossas. Porque aqui andaram as mulheres no meyo do conflito ajudando aos maridos, \&

\footnotetext{
16 Relaçam da vitória qve alcançov em dovs deste mês de Setembro, o General Martim Afonso de Melo, nos campos da Cidade d'Eluas, contra o inimigo Castelhano. 1641. Impressor: Manoel da Silva. f. 1. Itálico nosso. Ser "testemunha de vista", assim, traria a confiança dos leitores ao relato.

17 Qvarta Relaçam verdadeira da victoria, qve o fronteiro mor de Traslos Montes Ruy de Figueiredo de Alarcão ouue na sua fronteira, sinco legoas de Miranda, em Brandelhanes terra de Castella, em que por sua ordem se achou com elle Pedro de Mello Capitão mor de Mirãda. A qual mandou a sua Magestade o dito fronteiro mor assinada por sua mão \&c. 1641. Impressor: Jorge Rodriguez. f.2v.

18 Como exemplos, podemos citar: Relação dos svcessos, qve nas fronteiras deste Reyno tiuerão as armas DelRey Dom Joam o qvarto N. S. com as de Castella, despois da jornada de Montijo, ate fim do anno de 1644 com a victoriosa defensa de Eluas. 1645. Impressor: Antonio Alvarez; Relaçam de hua carta do Dovtor Ignasio Ferreira, do Dezembargo delRey Nosso Senhor \& outra de hum Religioso do Mosteiro de Bouro, em ' se referem alguas entradas, $q$ ' se fizerão no Reyno de Galiza. 1641. Impressor: Jorge Rodrigues; Relaçam da entrada qve fizeram em Galliza os gouernadores das armas da Prouincia de entre Douro, \& Minho o Mestre de Campo Violi de Athis, que por carta de Sua Magestade exercita o cargo de Mestre de Campo General, \& Manoel Telles de Menezes Gouernador do Castello de Vianna, \& Frey Diogo de Mello Pereira Cõmendador de Moura Morra, \& Veade da Religião de sam Joam de Malta, Capitam mor de Barcellos. 1642. Impressor: Domingos Lopes Rosa.

19 Relaçam das victorias qve o Mestre de Campo Dom Sancho Manoel alcançou dos inimigos Castelhanos por si só, \& em companhia do General Fernão Telles de Meneses, neste presente mês de Nouembro de 1642. Impressor: Antonio Alvarez. f. 2.
} 
carregando-Ihe os arcabuzes, para os descarregarem no castelhano, a que fizeram retirar, deixando à vista dos nossos mortos infantes, \& sessenta caualleiros, \& por aqui se pode entender o que seria de feridos. (...) Nam foy menor o zelo de hua mulher do mesmo lugar, que vendo entre os inimigos hum tio seu, que daquelle lugar se passara fugitivo para Castella, \& tornaua contra sua pátria, Ihe atirou com hua pedra, de que o matou, mostrando que a quem negaua sua pátria, os mesmos parentes por honra sua Ihe deuiam dar a morte. E sobre todos se realçou o feito de outra mulher, que na mesma villa matou de traz de hua porta com hua cachaporta a sete Castelhanos, imitação da celebre [forneita] de Aljubarrota, mas menos venturosa no successo, pois com dous pilouros a mataram por sima de hum telhado, que rosto a rosto nenhum Castelhano se atreueo ao fazer a sua cachaporra (sic). ${ }^{20}$

Certamente o leitor coevo se empolgaria com a descrição da participação dessas mulheres contra o exército castelhano. $\mathrm{O}$ castigo aos traidores era outro tema frequente nos papéis de notícias, em que podemos ler que recebiam a justiça divina em algum acidente ou eram descobertos e sentenciados à morte em locais públicos, para que servissem de exemplo. A notícia assim, coloca nas mãos de uma mulher a justiça em matar o parente que "negava sua pátria". Na sequência, vemos ainda que outra mulher foi a responsável pela morte de sete castelhanos, sendo comparada à "padeira de Aljubarrota", famosa na história popular de Portugal porque teria matado sete castelhanos com sua pá de padeira no dia da batalha de Aljubarrota (1350). Ainda que hoje em dia não se tenha certeza sequer se a história de Brites de Almeida foi real, sua lenda se espalhou através dos séculos e era utilizada justamente para inflar o patriotismo português contra os castelhanos, como podemos conferir na menção de seu nome na relação que trata da Restauração portuguesa quase trezentos anos depois. ${ }^{21}$

Gostaríamos ainda de trazer uma última citação a esta análise, que é a lembrança de Bandarra, inserida na relação que trata da retomada de Vila Viçosa e da batalha de Montes Claros impressa em Lisboa. ${ }^{22}$ Seu autor, depois de finalizar a descrição dos acontecimentos, afirma que "el célebre Bandarra predixo esta batalla, y la mortandad y gemidos de los vencidos, gran cabaña del Duque de Bragança Rey de Portugal, que él introduze con nombre de Pastor

\footnotetext{
${ }^{20}$ Facçoens ventvrosas qve tiverão na fronteira de Almeida o General Fernão Telles de Menezes, \& o Mestre de Campo D. Sancho Manoel contra o inimigo Castelhano em 2 \& 4 deste mês de Nouembro do anno presente 1642. Impressor: Domingo Lopes Rosa. f.4-4v.

21 Sobre o tema, ver também: CAMENIETZKI, Carlos Ziller. MEIRELLES, Rejane da Conceição. Frágeis damas e mulheres fortes: a representação feminina na Restauração de Portugal (1640-1668). In: Cad. Pagu (30), 2008. Neste artigo os autores também fazem menção à relação de sucesso que trata mulher que matou o próprio tio, discorrendo sobre a ideia de pátria para o período.

22 Essa relação pode ser chamada de relação historial, por buscar trazer uma descrição detalhada dos acontecimentos. O historiador Kleber Clementino afirma que "as relações historiais são muitas vezes contemporâneas das relações de sucessos e compartilham com elas, também, o compromisso de 'relatar', de enunciar eventos ainda em grande medida inéditos. Diferenciam-se, porém, pelo caráter de registro minucioso de que amiúde se revestem e pela ampliação da perspectiva com que subsumem os episódios particulares a contextos histórico-políticos de mais vasto escopo". SILVA, Kleber Clementino da. Política e historiografia nas narrativas lusocastelhanas seiscentistas da guerra holandesa no Atlântico Sul. Tese de Doutorado. Universidade Federal de Pernambuco. Recife: 2016. p. 38. A relação é atribuída a Antonio de Sousa de Macedo, secretário de Estado de Dom Afonso VI e está inserida no arquivo digital do Mercurio Portuguez disponibilizado pela Biblioteca Nacional de Portugal. Foi escrita em castelhano, como muitas publicações daquele período, buscando atingir um maior número de leitores.
} 
mayoral, en estes versos de sus bayles misteriosos"23 e insere, na sequência, os versos que entende terem sido escritos pelo sapateiro tratando daquela batalha:

Ao redor da grã Cabana
Naqueles Montes erguidos,
No Valle que se diz Cana.
Ouvimos esta somana
Lobos que andavão fugidos.
Dando grandes alaridos,
Fazendo grande agonia,
Muitos mortos, \& feridos,
Outros andavão fugidos,
Cae no bayle de Garcia 24

Macedo explica que a batalha de Montes Claros havia ocorrido próxima a um vale que chamavam Caña o que, portanto, confirmaria os versos de Bandarra que tratavam deste feito português.

O professor José Van Den Besselaar esclarece que quase tudo o que sabemos hoje sobre Gonçalo Anes de Bandarra se deve ao seu processo inquisitorial. Seu nascimento foi por volta do ano de 1500 na vila de Trancoso, onde passou toda a sua vida como sapateiro. Famoso na historiografia portuguesa graças às suas trovas, teve suas profecias relacionadas a diferentes reis durante dezenas de anos, sobretudo após o desaparecimento de Dom Sebastião na batalha de AlcácerQuibir - cuja falta de herdeiros deu origem à União Ibérica no ano de 1580. Mesmo enquanto vivia, suas trovas conheceram grande popularidade e, ainda que condenadas pela Igreja, agradavam "ao povo inculto e [atraíam] a curiosidade de diversos intelectuais, embora estes se sentissem um pouco embaraçados em manifestar abertamente o seu interesse por uma poesia tão pouco limada". 25

O Bandarra construído ao longo do seiscentos divergia do que conhecemos hoje sobre este personagem: atualmente sabemos que ele saberia ler e escrever, tinha acesso à Bíblia em vulgar e não era pobre. Naquele período, porém, o sapateiro era entendido como "um profeta rústico inspirado divinamente, enquanto dormia". ${ }^{26} \mathrm{O}$ que nos interessa aqui é compreender que suas trovas foram apropriadas por diferentes intérpretes, em diferentes períodos da História portuguesa, utilizadas para reafirmar novos reis - como dom João IV, mas também dom Afonso VI e dom Pedro II (especialmente pelo padre Antonio Vieira) - ou no retorno de um rei desaparecido, como o famoso dom Sebastião. De acordo com Luís Felipe Silvério Lima, há uma viragem ao longo da década de 20 do século XVII, realizada sobretudo pelos escritos de Bocarro, que transfere o Encoberto de dom Sebastião para os duques de Bragança: "Bocarro, que pertencia à rede de graças e mercês da casa ducal, indicou uma primeira viragem mais clara do

\footnotetext{
${ }^{23}$ Relacion Verdadera, y pontual, de la gloriosissima victoria que en la famosa batalla de Montes Claros Alcançó el Exercito delRey de Portugal... Con la admirable defensa de la plaça de Villa Viciosa. Lisboa. Con las licencias necesarias. En la Officina de Henriques Valente de Olivera, Impressor delRey nuestro Señor. Año 1665. f. 47.

${ }^{24}$ Idem, f. 48.

25 BESSELAAR, José Van Der. O sebastianismo. História sumária. Lisboa: ICLP, 1987. p. 46.

26 LIMA, Luís Filipe Silvério. O Império dos Sonhos. Narrativas proféticas, sebastianismo \& messianismo brigantino. São Paulo: Alameda, 2010. p. 147.
} 
sebastianismo para o messianismo brigantino". ${ }^{27}$ Assim, a espera do retorno de um rei português para governar passa de dom Sebastião para dom João IV e após sua morte, para seus descendentes. Padre Antonio Vieira, grande expoente da ideia de um destino português a frente da cristandade, não escrevia acerca de uma pessoa específica que iria governar Portugal, mas apenas que seria um Bragança. Foi, assim, "depositando suas esperanças nos reis e herdeiros brigantinos. Tanto que, com certa engenhosidade, pôde superar o engano sobre o infante falecido". 28

A apropriação de Antonio de Sousa de Macedo em sua relação sobre a batalha de Montes Claros não fugia à regra ao utilizar versos de Bandarra para confirmar o apoio divino aos soldados portugueses contra os castelhanos e a favor da nova Coroa. As Trovas de Bandarra perpassam a história portuguesa desde sua produção, no início do século XVI, até o século XIX, momento em que teve uma nova publicação, acrescida de novos capítulos. ${ }^{29}$ Os papéis produzidos com o intuito de divulgar as notícias das batalhas contra Castela, dessa forma - como representantes também de sua época - utilizaram, ainda que brevemente, as profecias de Bandarra como ilustrativas da preferência divina pelos portugueses.

\section{As relações madrilenas}

Apenas a partir de 1658 e sobretudo na década de sessenta do século XVII é que poderemos encontrar uma quantidade expressiva de relações de sucesso publicadas em Madrid sobre o conflito, enquanto em Lisboa houve certa diminuição nessa mesma época, possivelmente devido à publicação do Mercurio Portuguez. ${ }^{30}$ Nas décadas de 40 e 50 foram poucas as relações de sucesso encontradas em nossa investigação que tratassem de Portugal. Os impressos de notícias preocupavam-se com outros conflitos que envolviam a Monarquia Hispânica e pouco tratavam das questões portuguesas. Havia em Madrid a frequente publicação de manifestos

27 LIMA, Luís Felipe Silvério. O Império dos Sonhos... p. 254. Manuel Bocarro foi, de acordo com Jacqueline Hermann, um filósofo e matemático lusitano que, entre outras obras, escreveu a Anacephaleosis da monarquia lusitana, no ano de 1624. Dividida em quatro partes, a primeira delas, denominada Estado Astrológico, trouxe problemas a Bocarro - já em situação desconfortável diante do Santo Ofício devido às denúncias por judaizante de seu próprio irmão - por conter um discurso ambíguo que ora parecia uma celebração à dinastia reinante, ora demonstravam nostalgia e afronta ao monarca espanhol. Segundo Hermann, contudo, é em sua quarta parte, publicada somente na Itália no ano de 1626, depois de sair da prisão em Lisboa, que Bocarro consolida sua interpretação messiânica e original para o destino do reino português. Cf. HERMANN, Jacqueline. No reino do Desejado. A construção do sebastianismo em Portugal. Séculos XVI e XVII. São Paulo: Companhia das Letras, 1999.

28 LIMA. Luís Felipe Silvério. O Império dos Sonhos... p. 213. Ao receber a notícia que o herdeiro de Dom Pedro II e Maria Sofia havia nascido, padre Antonio Vieira afirmaria no 'Sermão de Ação de Graça pelo nascimento do príncipe D. João' que seria ele quem reinaria no Quinto Império, e que este seria português. A criança, contudo, morreria semanas depois.

29 Cf. HERMANN, Jacqueline. No Reino do Desejado...

30 O Mercúrio Portuguez foi um periódico de notícias escrito pelo secretário de Estado Antonio de Sousa de Macedo, dedicado exclusivamente às novas sobre a guerra. Foi publicado entre os anos de 1663 e 1667 de maneira mensal e ininterrupta, contribuindo também para fortalecer o novo rei no poder, Dom Afonso VI. Sobre o Mercúrio, ver: CARVALHO, Daniel Pimenta Oliveira de. Mais na opinião que nas forças. Antonio de Sousa de Macedo e a impressão do Mercurio Portuguez (1663-1667). Dissertação de mestrado. Rio de Janeiro. IFCS/Universidade Federal do Rio de Janeiro, 2009. 
contra dom João IV e a separação de Portugal, defendendo o direito de Felipe IV sobre a Coroa portuguesa, mas quanto às notícias que circulavam impressas pela cidade, eram muito poucas, num momento descrito por Fernando Dores Costa como uma "situação de trégua imperfeita" após a única batalha que contou de fato com o encontro dos dois exércitos, conhecida como batalha de Montijo, no ano de 1644. Ainda que existam relações de sucesso sobre essa batalha, não encontramos nenhuma que tenha sido impressa em Madrid, o que pode significar o pouco interesse da cidade sede da corte naquele momento com os acontecimentos na fronteira com Portugal. ${ }^{31}$

Encontramos, assim, apenas três papéis de notícias publicadas em Madrid que tratassem das batalhas contra Portugal anterior a 1658. Até esse ano, pouco se imprimia na cidade sobre os portugueses, mas o tratamento que os antigos vassalos de Felipe IV recebiam nos impressos noticiosos de Madrid se manteria durante toda a guerra: em todas as notícias os portugueses nunca são ridicularizados nem generalizados como rebeldes; o conflito teria sido gerado por um pequeno grupo, influenciado por um tirano - dom João IV ou dom Afonso VI. Obviamente dom João IV nunca é chamado de rei, apenas de "rebelde" ou "tirano", diferente do tratamento recebido nas relações de sucessos impressas em Barcelona, cujo inimigo comum fazia com que a realeza dos Braganças nunca fosse questionada. Tomemos como exemplo a Relacion fidedigna del feliz svcesso qve han tenido las armas de su Magestad Catolica, contra el Exercito del Rebelde de Portugal... 32 Este relato, escrito em primeira pessoa para que "se sirua de tenerlo entendido, y darla a su Magestad deste buen sucesso que hã tenido sus Reales Armas", escreve como teriam ocorrido as entradas do inimigo atrás de gado em terras castelhanas e a resposta do exército de Felipe IV. Depois de uma perda considerável de gado provocada pela entrada dos "rebeldes", a relação descreve a vingança dos soldados castelhanos, que teria terminado com mais de 150 mortos e 350 prisioneiros do lado inimigo, devendo-se ao "Cõde de Tronçán, y al Comissario General Maçacán, por auerlo obrado también", concluindo que "se assegure, que si aquí tuuieramos algunas fuerças, y medios de poder obrar, el Rebelde estuuiera a raya, y no se atreuiera a hazer entradas. Pero como la frontera es tan dilatada, y tan cortas nuestras fuerças, no es posible estoruarselo". Nas entrelinhas, o escritor reclamava, assim, da falta de forças do exército castelhano diante de uma fronteira tão grande como a que separava Castela de Portugal, nomeando os responsáveis pela (pequena) vitória. Mais uma vez chamamos a atenção para a definição do inimigo: é o rebelde e seus oficiais, não os portugueses. Foi bastante frequente durante toda a guerra a descrição desses "pequenos encontros" nas fronteiras, momento em que havia roubo de gado e mantimentos, que possuíam pouca relevância bélica, mas sempre bem relatados nos impressos de notícias.

31 Os impressos noticiosos sobre a batalha de Montijo foram discutidos em: CAMENIETZKI, Carlos Ziller. SARAIVA, Daniel Magalhães Porto. SILVA, Pedro Paulo de Figueiredo. O papel da batalha: a disputa pela vitória de Montijo na publicística do século XVII. In: TOPOI, v. 13 n. 24, 2012.

32 Relacion fidedigna del feliz svcesso qve han tenido las armas de su Magestad Catolica, contra el Exercito del Rebelde de Portugal: Sucedido media légua de Alcantara, junto a la Cruz, que llaman de Rebollo, a 6 de Março deste presente año de 1652. Impressor: Pablo de Val, 1652. 
Na década de 1660, contudo, é notável a dupla ofensiva que partiria de Madrid: a frente militar receberia o vitorioso general dom Juan José de Áustria e a frente da escrita começaria a produzir impressos noticiosos para combater as publicações portuguesas. ${ }^{33}$ Foi a partir dessa época, assim, que as notícias relacionadas a Portugal passaram a aparecer com maior frequência nas oficinas impressoras de Madrid. Julián de Paredes, além de trazer à luz a Gazeta Nueva, passou a publicar ainda algumas relações de sucesso com notícias da guerra. ${ }^{34}$ Junto a ele, encontramos Francisco Nieto, Joseph Buendía e Domingo García Morrás, além de Diego Diaz. Passar a imprimir notícias sobre a guerra da Restauração demonstra, assim, não só o interesse de um público leitor pelo tema, mas o fim dos demais conflitos em que a Monarquia Hispânica estava inserida e a retomada das batalhas na fronteira com Portugal, já que no ano seguinte seria celebrada a Paz dos Pirineus com a França.

Dessa forma, no ano de 1658 encontramos três relações impressas em Madrid, duas por Julian de Paredes e uma por Diego Diaz. As publicações de Paredes tratam da mesma região da Galícia, enquanto a de Diaz descreve o ocorrido no sul da fronteira, em Estremoz. Assim, na Relacion de la famosa vitoria que han tenido las Catolicas Armas de su Magestad, que Dios guarde... ${ }^{35}$ e na Copia de vna carta remitida desde el campo sobre Monçon, en las fronteras de Portugal, à vn Cauallero de esta Corte... ${ }^{36}$ encontramos a descrição dos acontecimentos para aquele ano na região entre Douro e Minho. Na primeira relação podemos ler o ocorrido em setembro sobre a entrada em Portugal do exército comandado por Dom Baltasar de Roxas y Pantojas e pelo marquês de Peñalva Dom Bernardino de Meneses. Chamamos a atenção aqui na identificação do exército como galego durante todo o documento, sempre enfatizando seu valor:

los quales pelearon con tanto desnuedo, y valentía, que co auer el enemigo ocupado los mejores puestos, no pudo resistir el ímpetu de nuestra gente, que entrando por la Vanguardia del Exercito Portugues, salio por la retaguardia, abriendo, y deshaziendo los escuadrones de tal forma, que perecio la mayor parte de los enemigos. (...) Y generalmente hablado, todo el Exercito de Galicia obró en esta ocasión, como en todas las demas, tan valerosamente, que no les hacen

\footnotetext{
${ }^{33}$ HERMANT, Heloise. La actualidad de la Guerra de Restauración de Portugal entre cartas, relaciones de sucesos y gacetas. Tensión editorial y decifración del acontecimiento. In: CIAPELLI, Giovanni. NIDER, Valentina (eds.) La invención de las noticias. Las relaciones de sucesos entre la literatura y la información (siglos XVI-XVIII). Trento: Università degli Studi di Trento. Departimento di Lettere e Filosofia, 2017. p. 299-319.
}

${ }^{34}$ A Gazeta Nueva é o primeiro periódico de notícias impresso em Madrid e foi por muito tempo considerado o primeiro da Espanha. Era publicado pelo secretário do general Dom Juan José de Áustria (filho bastardo de Felipe IV), chamado Fabro Bremundán, e trazia notícias de diversas partes da Europa, relatando também a situação nas fronteiras com Portugal e o envio do general para enfrentar "os rebeldes". Foi impressa mensalmente entre 1661 e 1663. Sobre a Gazeta Nueva, ver: VARELA HERVIAS, Eulogio. Gazeta Nueva 1661-1663 (notas sobre la historia del Periodismo Español en la segunda mitad del siglo XVII. Madrid; Murcia: Oficina Tipográfica de los sucesores de Nogués, 1960; HERMANT, Heloise. La actualidad de la Guerra de Restauración de Portugal...

35 Relacion de la famosa vitoria que han tenido las Catolicas Armas de su Magestad, que Dios guarde, governadas por el Excelentissimo señor Don Rodrigo Pimentel Marques de Viana, Gouernador y Capitan General del Reino de Galicia. Contra las de los Rebeldes del Reino de Portugal. Impressor: Julián de Paredes, 1658.

36 Copia de vna carta remitida desde el campo sobre Monçon, en las fronteras de Portugal, à vn Cauallero de esta Corte, dándole cuenta de lo sucedido en quitarles a los Portugueses el socorro que querían introducir por el Miño a dicha Plaça. Sucedido el Sabado siete deste presente mes de Diziembre de 1658. Impressor: Julián de Paredes, 1658. 
ventaja los Soldados mas expertos de los Paises de Flandes, y de Italia. (...) Con esta vitoria, conseguida por los valerosos, y esforçados Gallegos, quedaron los Portugueses tan amedrentados, que no teniéndose por seguros dentro de su Castillo, o Fortaleza, se huyeron del Exercito por aquellos Montes (...). ${ }^{37}$

Demonstrar o valor dos homens daquela região era certamente parte da função deste documento, que enfatiza que eles eram melhores do que os soldados vindos de outras regiões da Monarquia, numa clara busca por reconhecimento diante de seu rei.

Apesar da mudança no título do documento, a carta que se publica na sequência tem o mesmo formato e aparentemente foi escrita pela mesma pessoa, pois podemos ler logo no início que "continuando con lo que V.m. me manda en sus cartas le auise, y de cuenta por menor de lo que va sucediendo con los Portugueses en la Prouincia entre Duero, y Miño le siruo con vna breue suma (...)." A cópia da carta descreve apenas mais uma entrada bem sucedida em terras portuguesas, que ocorreu no dia 7 de dezembro daquele ano. À diferença da relação de sucesso anterior, esse impresso apresenta a data em que foi escrita e o local: "del campo sobre Monçon a 10 de Diziembre de 1658 años", mantendo o formato de uma missiva. Essas chamadas "epístolas de relación" são compreendidas por Pedro M. Cátedra como a voz do protagonista (pois escritas em primeira pessoa), possuindo uma "función ritualizadora de la acción heroica y de las relaciones con el Rey", beneficiando não só o protagonista, mas também sua família e linhagem. ${ }^{38}$ Não só Cópias de Carta como vimos acima, mas as relações de sucesso que discorrem sobre serviços prestados às respectivas Coroas podem ser entendidos também, nas palavras de Cátedra, como pliegos de méritos, já que buscam enaltecer as façanhas ora de uma pessoa que esteve em campo, ora de todo um grupo, como os galegos da relação anterior. Além disso, o formato que apresentam enquanto fragmento que acabara de chegar do campo de batalhas possui a função de uma "janela de realidade", como aborda o historiador Daniel Saraiva, de que aquele impresso não seria apenas uma versão dos acontecimentos, mas possuiria a verdade dos fatos. ${ }^{39}$

Assim como em Lisboa, também encontramos dentre as relações madrilenas o formato de relações seriadas. Recuperamos dois grupos de relações do ano de 1662, cujos títulos foram colocados no anexo 2 ao final deste texto, bem como o período ao qual o impresso se refere. Nos títulos das relações de sucesso do primeiro conjunto, podemos ler a descrição diária da movimentação dos exércitos e dos resultados obtidos devido, sobretudo, ao comandante dom Juan José de Áustria. Na terceira delas, devido aos sucessos obtidos na campanha, afirma-se que "partiremos de aquí mañana, no se sabe a donde, pero yendo como va este negocio, nos

\footnotetext{
37 Relacion de la famosa vitoria que han tenido las Catolicas Armas de su Magestad, que Dios guarde... f. 2. Itálico nosso.

38 CÁTEDRA, Pedro M. En los orígenes de las epístolas de relación. In: GARCÍA DE ENTERRÍA, María Cruz. et al. (eds.) Las relaciones de sucesos en España (1500-1750). Actas del primer Coloquio Internacional. Alcalá e Henares: Publications de la Sorbonne; Servicio de Publicaciones de la Universidad de Alcalá, 1996. p. 42.

39 SARAIVA, Daniel. As janelas da realidade: a função política das relações de sucessos na Guerra da Restauração de Portugal (1640-1668) In: GARCÍA LÓPEZ, Jorge. BOADAS, SÒNIA (eds) Las relaciones de sucesos en los cambios políticos y sociales de la Europa Moderna. Atas da Siers. Universitat Autònoma de Barcelona; Servei de Publicacions: Bellaterra, 2015.
} 
juzgamos ir à Lisboa". ${ }^{40} \mathrm{O}$ otimismo expresso no papel era tanto que já supunham partir em direção de Lisboa para a tomada da cidade - ou era isso o que gostariam que seu leitor pensasse. Escreve ainda que "ellos tienen famoso miedo a Su Alteza, y estos días se han venido a rendir algunos soldados de acauallo, Franceses, y Portugueses, y todos conuienen en que mueren de hambre, y que nos les pagan (...)." Descrever assim, não só o medo que sentiriam de dom Juan José de Áustria como a péssima situação do exército inimigo é parte do interesse de desqualificar os "rebeldes" e demonstrar que estão passando fome e perdendo soldados. No quarto diário... encontramos mais uma vez a superioridade do exército castelhano sendo descrita quando lemos que "no se ha oído sucediesse muerte, violación de mugeres, ni robos en la Iglesia, de que su Alteza quedó muy gozoso, porque en días de tanta confusión, y horror no suele ser fácil euitar estos acidentes (...)."41 A acusação de que estes soldados não respeitavam os templos religiosos e eram extremamente violentos com a população era uma aparição frequente nos papéis portugueses, cabendo assim, responder que essas ações eram "acidentes," e que não haviam ocorrido naquelas entradas.

No segundo conjunto de relações, que trata da região da Galícia, na primeira delas vemos novamente a menção ao saque das igrejas, onde mais uma vez se demonstra que aquilo não era concebível para os comandantes castelhanos:

y porque de una Iglesia sacarõ algunas cosas los soldados, mando el señor Marques prenderlos (...) dando con esto a vn tiempo satisfacion a Dios, y al mundo del atreuimiento, acción muy digna de su zelo, y prudencia, con que puso freno a la variedad de Naciones de que se compone el Exercito. ${ }^{42}$

Neste trecho a ideia é ainda afirmar que não eram os castelhanos quem estariam saqueando as igrejas, mas soldados de várias nações que compunham aquele exército. Mais uma vez, o que nos parece ser uma frequência nos papéis que tratam das batalhas na região da Galícia, encontramos o enaltecimento dos soldados galegos: "no es creible el valor con que los Gallegos, y las Naciones han obrado, y obran, y muy hermanablemente, y en los choques, y auances andan a porfia obre quien ha de ser primero; con $q^{\prime}$ han obrado lo que se sabe, dexando al enemigo muy medroso (...)."43

\footnotetext{
${ }^{40}$ Relacion verdadeira, y tercer Diario de la fez vitória que han tenido las Catolicas Armas de Su Magestad (que Dios guarde) contra el Rebelde de Portugal, governadas, y assistidas por su Alteza el Serenissimo señor Don Iuan de Austria en los rendimientos, y tomas de las plaças de Beyros, y Monforte. Impressor: Francisco Nieto. f. 2.

${ }^{41}$ Relacion Verdadera, y quarto Diario de la feliz vitória que han tenido las Catolicas Armas de Su Magestad (que Dios guarde) contra el Rebelde de Portugal, governadas, y assistidas por su Alteza el Serenissimo señor Don Iuan de Austria, en el sitio, y toma de la villa de Ocrato, con otros doze lugares de su Priorato, que sus nombres van al fin desta relación. Impressor: Francisco Nieto. f.1v.

42 PRIMERA relacion diaria de los felizes sucessos que las armas de su Magestad (que Dios guarde) tuuieron contra el Rebelde de Portugal entre Duero, y Miño, este año de 1662. Impressor: Francisco Nieto. f.1v.

43 TERCERA Relacion diaria de todo lo svcedido desde el dia diez de Agosto hasta 21 del dicho, al Exercito de su Magestad en la Conquista del Reyno de Portugal por la parte de Galicia, assistido, y gouernado por el Ilustrissimo Señor Don Pedro Carrillo, Arçobispo de Santiago, Capitan General de dicha Conquista, y el señor Don Baltasar Pantoja, Maestre de Campo General, y el Excelentissimo Señor Marques de Penalva, Capitan General de la Caualleria. Impressor: Joseph Fernandes Buendía. f. 2.
} 
Nestas relações podemos ler a descrição detalhada do movimento dos exércitos dia após dia, com o cuidado de nomear os principais comandantes frente aos exércitos e sempre contra "o rebelde de Portugal". Nestes papéis é mais comum enaltecer os próprios soldados e comandantes do que inferiorizar os portugueses. Com o intuito de que esses impressos cruzassem a fronteira, as relações traziam ainda informações sobre moradores que passavam a lutar do lado castelhanos, "porque desejam se ver livres das opressões, tiranias e tributos que padecem." 44

Outras relações também são impressas no mesmo ano de 1662, como a que se chama "Copia de carta escrita de vn cortesano de Lisboa a vn ciudadano de Cadiz, en que le dá quenta de algunas cosas que allá pasan, traducida de Portugues en Castellano". Nessa relação podemos ler, novamente em primeira pessoa, sobre todas as vitórias de Castela e como isso estaria afetando a população " $q$ ' somos (aunque Portugueses) Castellanos en el efecto a nuestro Rey". 45 O autor da carta escreve ainda que "lo mas que tiene a este Reyno triste, es, ver que en Castilla, por todas partes, se preuiêne gruessos, y numerosos Exercitos para esta Primauera, y esperan mucho daño, y acá no ay oposición, ni es posible jûtar vn tostón, ni vn hombre". ${ }^{46} \mathrm{~A}$ impressão, publicada como se fosse uma carta enviada de Portugal, visa assim demonstrar não só as vitórias castelhanas, como o apoio do povo português a Felipe IV e seu descontentamento com as decisões tomadas pela Coroa portuguesa, discorrendo ainda sobre o sofrimento dos moradores da cidade de Lisboa com a falta de mantimentos e o caro preço dos alimentos.

A última relação de sucesso que encontramos impressa em Madrid é também publicada em formato de carta dando notícias sobre a tomada da cidade de Évora na região do Alentejo. A Copia de carta venida del Exercito, en que se auisa la toma de Ebora Ciudad, y el feliz sucesso de las Armas de su Magestad, que Dios Guarde descreve já no ano de 1663 a importância daquele feito, que teria deixado Lisboa "inquieta", já que era uma cidade no "coração do Alentejo" e "a dez léguas de Lisboa", exagerando a proximidade das duas cidades. Este é o último impresso noticioso publicado em Madrid que conseguimos encontrar, silêncio que pode se dever à derrota seguida por dom Juan José de Áustria em Évora no fim do mesmo mês. Dessa forma, o silêncio que encontramos após junho de 1663 demonstra como as relações poderiam trazer apenas notícias que favorecessem o governo de Felipe IV, tendo em vista as constantes derrotas sofridas por seus exércitos a partir de então. Importante ressaltar ainda que, apesar de encontrarmos uma maior quantidade de relações de sucesso madrilenas sobre o conflito com Portugal na década de 1660, nesse momento já havia uma diminuição na publicação de impressos informativos em todo o território espanhol. A grande quantidade de publicações de

${ }^{44}$ Qvarta relacion diaria de todo lo svcedido desde el dia 21 de Agosto, hasta 14 de Septiembre deste año de 1662 al exercito de su Magestad en la Conquista del Reyno de Portugal por la parte de Galicia, assistido, y gouernado por el Illustrissimo Señor Pedro Carrillo, Arçobispo de Santiago, Capitan General de Dicha Conquista; y señor D. Baltasar Pantoja, Maestre de Campo General, y el Excelentissimo Señor Marques de Penalva, Capitan General de la Caualleria. Impressor: Joseph Fernandes Buendía. f. 2. Tradução nossa.

45 Copia de carta escrita de vn cortesano de Lisboa a vn ciudadano de Cadiz, en que le dá quenta de algunas cosas que allá pasan, traducida de Portugues en Castellano. Impressor: Francisco Nieto. f.1v.

46 Ibidem. f. 2-2v. 
relações de sucesso em todo o continente começou no século XVI e atingiu seu auge na primeira metade do século XVII, começando a diminuir a partir da década de 1650.

\section{Considerações finais}

Esperamos que a discussão proposta tenha conseguido demonstrar a importância do estudo das relações de sucesso a partir de uma visão mais ampla dos que as fronteiras atuais.

Como diferentes pesquisadores vem evidenciando nos últimos anos, a circulação de notícias através de publicações impressas é um fenômeno encontrado em todo o território europeu. Ainda que os estudos sobre Portugal sejam mais escassos, o mundo Ibérico é parte de uma rede informativa e também se utiliza desses papéis para informar e conseguir adeptos às suas causas. Enquanto o auge português de publicação de relações de sucesso se deu em um momento fundamental de sua História, ou seja, a partir da separação dos domínios de Felipe IV e sua autonomia com a nova Coroa, Henry Ettinghausen argumenta que, para a Espanha, o ápice ocorreu no momento em que a crise econômica e política já começava a ser anunciada pelos arbitristas, ainda no fim do século XVI. ${ }^{47}$ Não é de se espantar, assim, que Portugal tome frente nas publicações, tendo em vista a diminuição das impressões em todo o território espanhol e mesmo sua preocupação com outras frentes de batalha. Comparando esses impressos para além de uma análise regional, conseguimos estabelecer semelhanças e diferenças no tratamento dado aos inimigos, compreender as maneiras de "responder" aos ataques que vinham também a partir da escrita e analisar o uso dessas notícias como "pliegos de méritos", como explica Cátedra, ao serem utilizadas para enaltecer oficiais que prestavam serviços nos campos de batalha.

Dessa forma, discorremos sobre o intuito de exaltar os oficiais na guerra, individualmente ou de uma região específica, além de "atacar," através dos escritos, os soldados inimigos. Enquanto os papéis madrilenos identificavam o "rebelde" e seu grupo, desculpando os portugueses e reafirmando seu pertencimento à Monarquia Hispânica como vassalos de Felipe IV, os impressos lisboetas traziam uma série de características negativas sobre o inimigo - como hereges, violentos e covardes - e reiteravam sua fidelidade ao novo rei. Tanto os papéis impressos em Lisboa como os de Madrid afirmavam também que os habitantes das fronteiras estariam mudando de lado, buscando enfatizar o apoio encontrado por seus soldados durante o conflito.

Outro ponto que buscamos ressaltar era o formato desses impressos e a existência de publicações "intermediárias" entre relações de sucesso e periódicos, que chamamos de relações seriadas. Os Anexos 1 e 2 pretendem demonstrar, a partir dos títulos e da frequência de impressão - evidenciada ou pelo período do qual a relação tratava ou com a data de taxação -,

47 ETTINGHAUSEN, Henry. La prensa preperiódica española y el Barroco. In: CÁTEDRA GARCÍA, Pedro M. (dir.) Géneros Editoriales y Relaciones de Sucesos en la Edad Moderna. Sociedad Internacional para el Estudio de las Relaciones de Sucesos. Seminario de Estudios Medievales y Renacentistas: Salamanca, 2013. 
como essas relações procuravam discorrer de maneira sequencial sobre os acontecimentos bélicos, transformando-se quase em um diário da guerra onde os leitores poderiam acompanhar o dia-a-dia do possível autor da notícia/carta. O formato das relações de sucesso visava passar aos leitores a ideia de verdade e relações seriadas como as encontradas traziam ainda mais o sentimento de um relato fidedigno dos acontecimentos.

Pouco lembradas nos relatos de guerra, as mulheres também apareceram nas relações portuguesas como exemplo de força e determinação, exaltando um grupo que normalmente não participaria ativamente do conflito. As profecias de Bandarra, famosas na História portuguesa, também foram utilizadas nesses papéis para confirmar a superioridade de Portugal diante dos castelhanos, já que indicariam uma preferência divina pela Coroa brigantina e sua permanência à frente daquele reino. 


\section{Anexo 1}

Relaçam do svcesso qve Ruy de Figveiredo fronteiro d'Arraya de tralos montes teue na entrada que fez no Reyno de Galiza. Manuel da Silva. Setembro de 1641. Taxada em 07 de setembro de 1641 ;

Segvnda relaçam verdadeira e algvns svcessos venturosos $q$ ' teue Ruy de Figueiredo Fron[]iro mor da Villa de Chaues, na entrada que fez, \& ordenou em algus lugares do Reyno de Galiza, nos vitimos dias de Agosto até se recolher a dita villa: copiada de hua carta que o dito Frõteiro enuiou a S. Magestade. Manuel da Silva. Setembro de 1641. Taxada em 28 de setembro de 1641 ;

Terceira Relaçam do sucesso, que teve Rui de Figueiredo de Alarcão nas fronterias de Chaves, Monte Alegre \& Monforte, segunda feira, nove do mês de setembro de 641. de que he general \& fronteiro mor, tirada da carta que escreveo a sua majestade. Jorge Rodrigues. Outubro de 1641. Taxada em 15 de outubro de 1641;

Qvarta Relaçam verdadeira da victoria, qve o fronteiro mor de Traslos Montes Ruy de Figueiredo de Alarcão ouve na sua fronteira, sinco legoas de Miranda, em Brandelhanes terra de Castella, em que por sua ordem se achou com elle Pedro de Mello Capitão mor de Mirãda. A qual mandou a sua Magestade o dito fronteiro mor assinada por sua mão \&c. Jorge Rodrigues. Novembro de 1641. Taxada em 18 de novembro de 1641.

\section{Anexo 2}

Relacion verdadera, y diario de lo sucedido en la entrada que há hecho el serenissimo señor Don Iuan de Austria, com las catolicas armas de su Magestad em la campaña i tierras del Rebelde de Portugal desde el dia primero de mayo deste año de 1662. Impressor: Francisco Nieto [01 de maio a 16 de maio];

Relacion verdadera, y segvndo Diario de la feliz vitória que han tenido las Catolicas Armas de su Magestad (que Dios guarde) contra el Rebelde de Portugal, governadas, y assistidas por su Alteza el Serenissimo señor Don Juan de Austria, en el sitio y toma de de Iurumeña. Impressor: Francisco Nieto [17 de maio a 12 de junho];

Relacion verdadera, y tercer Diario de la feliz vitoria que han tenido las Catolicas Armas de su Magestad (que Dios guarde) contra el Rebelde de Portugal, gouernadas, y assistidas por su Alteza el Serenissimo señor Don Uian de Austria em los rendimientos, y tomas de las plaças de Beyros, y Monteforte. Impressor: Francisco Nieto [23 de junho a 27 de junho];

Relacion Verdadera, y quarto Diario de la feliz vitória que han tenido las Catolicas Armas de Su Magestad (que Dios guarde) contra el Rebelde de Portugal, governadas, y assistidas por su 
Alteza el Serenissimo señor Don Iuan de Austria, en el sitio, y toma de la villa de Ocrato, con otros doze lugares de su Priorato, que sus nombres van al fin desta relación. Impressor: Francisco Nieto [28 de junho a 08 de julho].

Primera relación diaria de los felizes sucessos que las armas de su Magestad (que Dios guarde) tuuieron contra el Rebelde de Portugal entre Duero, y Miño, este año de 1662. Impressor: D. Francisco Nieto [04 de junho a 02 de agosto];

Segvnda relacion diaria de la feliz Vitoria que han tenido las Catolicas Armas de su Magestad (que Dios guarde) por la parte de Galicia, contra el Exercito Rebelde de Portugal, gouernadas por los Señores D. Baltasar Pantoja y el Marqués de Penalva. Donde se declara el numero de muertos, y prisioneros que ha auido en los dos encuentros. Impressor: Francisco Nieto [08 de agosto a 10 de agosto];

Tercera Relacion diaria de todo lo svcedido desde el dia diez de Agosto hasta 21 del dicho, al Exercito de su Magestad en la Conquista del Reyno de Portugal por la parte de Galicia, assistido, y gouernado por el Ilustrissimo Señor Don Pedro Carrillo, Arçobispo de Santiago, Capitan General de dicha Conquista, y el señor Don Baltasar Pantoja, Maestre de Campo General, y el Excelentissimo Señor Marques de Penalva, Capitan General de la Caualleria. Impressor: José Fernandez Buendía [10 de agosto a 21 de agosto];

Qvarta relacion diaria de todo lo svcedido desde el dia 21 de Agosto, hasta 14 de Septiembre deste año de 1662 al exercito de su Magestad en la Conquista del Reyno de Portugal por la parte de Galicia, assistido, y gouernado por el Illustrissimo Señor Pedro Carrillo, Arçobispo de Santiago, Capitan General de Dicha Conquista; y señor D. Baltasar Pantoja, Maestre de Campo General, y el Excelentissimo Señor Marques de Penalva, Capitan General de la Caualleria. Impressor: José Fernandez Buendía [21 de agosto a 14 de setembro];

Qvinta Relacion diaria de lo svcedido a las católicas Armas de su Magestad (que Dios guarde) en la frontera de Portugal, por la parte de Galicia, donde se dá cuenta, y declara los sucessos de mar, y tierra, que han passado, desde el dia treze deste mes de Setiembre, lasta el dia diez y nueue del dicho; assi las presas, municiones, y pertrechos, que les hemos tomado, como los Nauios, y Baxeles. Y como nuestro Exercito está sobre Moreyra, gouernado por el Ilustrisimo, y Excelentisimo señor Arçobispo de Santiago, y Excelentissimo señor D. Baltasar Pantoja, Maestre de Campo General; y el Excelentissimo señor Marques de Penalua, Capitan General de la Caualleria. Impressor: José Fernandez Buendía [13 de setembro a 19 de setembro];

Sexta relacion verdadera de los felices sucessos, y vitorias que han tenido las Armas de la Magestad Catolica del Rey nuestro Señor Don Felipe Quarto (que Dios guarde) governadas, y assistidas por el Ilustrissimo señor D. Pedro Carrillo de Acuña, Arçobispo de Santiago: y el Excelentissimo señor Don Baltasar Pantoja, Maestre de Campo General de aquel Exercito: y el Excelentissimo señor Marques de Penalva, Capitan general de la Caualleria, desde 24 de agosto, hasta 25 de setiembre, que se rindió la Plaça de Moreyra. Impressor: Domingo Garcia Morras [25 de agosto a 25 de setembro]; 


\section{Referências}

ABLASTER, Paul. et al. The lexicons of Early Modern News. In: RAYMOND, Joad. MOXHAM, Noah (ed.) News Networks in Early Modern Europe. Brill: Leiden; Boston, 2016;

BAENA SÁNCHEZ, Francisco. ESPEJO CALA, Carmen. En busca de un vocabulario compartido para describir y representar el periodismo de la Edad Moderna. In: CIAPELLI, Giovanni. NIDER, Valentina (eds.) La invención de las noticias. Las relaciones de sucesos entre la literatura y la información (siglos XVI-XVIII). Trento: Università degli Studi di Trento. Departimento di Lettere e Filosofia, 2017;

BELO, André. As Gazetas e os Livros. A Gazeta de Lisboa e a vulgarização do impresso (17151760). Lisboa: Instituto de Ciências Sociais, 2001;

BESSELAAR, José Van Der. O sebastianismo. História sumária. Lisboa: ICLP, 1987;

CAMENIETZKI, Carlos Ziller. MEIRELLES, Rejane da Conceição. Frágeis damas e mulheres fortes: a representação feminina na Restauração de Portugal (1640-1668). In: Cad. Pagu (30), 2008;

CAMENIETZKI, Carlos Ziller. SARAIVA, Daniel Magalhães Porto. SILVA, Pedro Paulo de Figueiredo. O papel da batalha: a disputa pela vitória de Montijo na publicística do século XVII. In: TOPOI, v. 13 n. 24, 2012;

CARDIM, Pedro. Portugal Unido y Separado. Felipe II, la unión de territorios y el debate sobre la condición política del Reino de Portugal. Valladolid: Cátedra Felipe II; Ediciones Universidad de Valladolid, 2014;

CARVALHO, Daniel Pimenta Oliveira de. Mais na opinião que nas forças. Antonio de Sousa de Macedo e a impressão do Mercurio Portuguez (1663-1667). Dissertação de mestrado. Rio de Janeiro. IFCS/Universidade Federal do Rio de Janeiro, 2009;

CÁTEDRA, Pedro M. En los orígenes de las epístolas de relación. In: GARCÍA DE ENTERRÍA, María Cruz. et al. (eds.) Las relaciones de sucesos en España (1500-1750). Actas del primer Coloquio Internacional. Alcalá e Henares: Publications de la Sorbonne; Servicio de Publicaciones de la Universidad de Alcalá, 1996;

CÁTEDRA GARCÍA, Pedro M. (dir.) Géneros Editoriales y Relaciones de Sucesos en la Edad Moderna. Sociedad Internacional para el Estudio de las Relaciones de Sucesos. Seminario de Estudios Medievales y Renacentistas: Salamanca, 2013;

COSTA, Fernando Dores. A Guerra da Restauração 1641-1668. Lisboa: Livros Horizonte, 2004; COSTA, Leonor Freire. CUNHA, Mafalda Soares da. D. João IV. Círculo de Leitores, Lisboa, 2008; ETTINGHAUSEN, Henry. Noticias del siglo XVII: Relaciones Españolas de sucesos naturales y sobrenaturales. Barcelona: Puvill Libros, 1995;

ETTINGHAUSEN, Henry. Prensa amarilla y Barroco español. In: CHARTIER, Roger. ESPEJO Carmen (eds.) La aparición del periodismo en Europa. Comunicación y propaganda en el Barroco. Marcial Pons: Madrid, 2012;

ETTINGHAUSEN, Henry. Relaciones Internacionales: las relaciones de sucesos, un fenómeno paneuropeo. In: GARCÍA LÓPEZ, Jorge. BOADAS, Sònia (eds.) Las relaciones de sucesos en los cambios políticos y sociales de la Europa Moderna. Sociedad Internacional para el Estudios de 
las Relaciones de Sucesos. Universitat Autònoma de Barcelona; Servei de Publicacions: Bellaterra, 2015;

FRANÇA, Eduardo d'Oliveira. Portugal na Época da Restauração. Hucitec: São Paulo, 1997;

HERMANN, Jacqueline. No reino do Desejado. A construção do sebastianismo em Portugal. Séculos XVI e XVII. São Paulo: Companhia das Letras, 1999;

HERMANT, Heloise. La actualidad de la Guerra de Restauración de Portugal entre cartas, relaciones de sucesos y gacetas. Tensión editorial y decifración del acontecimiento. In: CIAPELLI, Giovanni. NIDER, Valentina (eds.) La invención de las noticias. Las relaciones de sucesos entre la literatura y la información (siglos XVI-XVIII). Trento: Università degli Studi di Trento. Departimento di Lettere e Filosofia, 2017;

LIMA, Luís Filipe Silvério. O Império dos Sonhos. Narrativas proféticas, sebastianismo \& messianismo brigantino. São Paulo: Alameda, 2010;

MEGIANI, Ana Paula Torres. Contar coisas de todas as partes do mundo: as Relaciones de Sucesos e a circulação de notícias escritas no período filipino. In: ALMEIDA, Suely Creusa Cordeiro de. SILVA, Gian Carlo de Melo. RIBEIRO, Marília de Azambuja (orgs.) Cultura e sociabilidades no mundo atlântico. Recife: Ed. Universitária da UFPE, 2012;

SARAIVA, Daniel. As janelas da realidade: a função política das relações de sucessos na Guerra da Restauração de Portugal (1640-1668) In: GARCÍA LÓPEZ, Jorge. BOADAS, SÒNIA (eds) Las relaciones de sucesos en los cambios políticos y sociales de la Europa Moderna. Atas da Siers. Universitat Autònoma de Barcelona; Servei de Publicacions: Bellaterra, 2015;

SCHOBESBERGER, Nikolaus. et. al. European Postal Network. In: RAYMOND, Joad. MOXHAM, Noah (ed.) News Networks in Early Modern Europe. Brill: Leiden; Boston, 2016;

SILVA, Kleber Clementino da. Política e historiografia nas narrativas lusocastelhanas seiscentistas da guerra holandesa no Atlântico Sul. Tese de Doutorado. Universidade Federal de Pernambuco. Recife: 2016;

VALLADARES, Rafael. A independência de Portugal. Guerra e Restauração (1640-1680). Trad. de Pedro Cardim. A Esfera dos Livros: Lisboa, 2006;

VALLADARES, Rafael. Portugal y la Monarquía Hispánica 1580-1668. Arco Libros: Madrid, 2000;

VARELA HERVIAS, Eulogio. Gazeta Nueva 1661-1663 (notas sobre la historia del Periodismo Español en la segunda mitad del siglo XVII. Madrid; Murcia: Oficina Tipográfica de los sucesores de Nogués, 1960. 